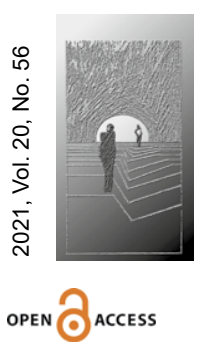

Magdalena Kolber

http://orcid.org/0000-0002-8227-5475

Uniwersytet Kazimierza Wielkiego magkol@ukw.edu.pl DOI: 10.35765/hw.2096

\title{
Rola środowiska ucznia w rozwijaniu samoregulacji w uczeniu się w czasie edukacji zdalnej
}

\section{STRESZCZENIE}

CEL NAUKOWY: Celem artykułu jest ukazanie roli środowiska i zasobów społecznych ucznia w rozwijaniu samoregulacji w uczeniu się podczas nauczania zdalnego w trakcie pandemii COVID-19.

PROBLEM I METODY BADAWCZE: Przedstawiony w pracy problem badawczy dotyczy odpowiedzi na pytania: Czym jest uczenie się samoregulowane? Jaka jest rola środowiska domowego i zasobów społecznych ucznia w rozwijaniu samoregulacji w uczeniu się podczas nauczania zdalnego? Jaka jest rola dorosłych osób w organizowania środowiska uczenia się? Czy korepetycje sprzyjają zachowaniom strategicznym? Zastosowano metodę analizy i krytyki piśmiennictwa literatury przedmiotu.

PROCES WYWODU: Na podstawie dostępnych w literaturze modeli opracowano sylwetkę ucznia o wysokim stopniu samoregulacji w uczeniu się. Zaprezentowano oraz dokonano analizy wyników badań dotyczących wpływu znaczących osób ze środowiska domowego na rozwój umiejętności uczenia się dziecka. Wyjaśniono, w jaki sposób działania rodziców i korepetytorów mogą wspomóc szkołę w tworzeniu warunków do uczenia się w czasie edukacji zdalnej.

WYNIKI ANALIZY NAUKOWEJ: Praca prezentuje szerokie spojrzenie na wspomaganie ucznia w uczeniu się, jak się uczyć. Z przeprowadzonych analiz wynika, że umiejętność uczenia się może być rozwijana przez znaczące osoby ze środowiska ucznia na rozmaite sposoby. Pokazano również, że indywidualna praca korepetytora z uczniem nie sprowadza się tylko do wyrównania braków w nauce, ale polega też na przygotowaniu do samokształcenia. Określone przekonania dorosłego oraz wynikające z nich komunikaty wobec dzieci wpływają na dalsze działania uczącego się w zakresie uczenia się.

WNIOSKI, INNOWACJE, REKOMENDACJE: Znaczący dorosły odgrywa bardzo ważną rolę w kształtowaniu samoregulacji w uczeniu się. Zaangażowanie oraz wykorzystanie zasobów społecznych ucznia stanowi kluczowy element zdalnej edukacji. Z tego względu poszerzanie wiedzy wśród rodziców na temat rozwijania uczenia się samoregulowanego powinno być priorytetowym zadaniem pracowników edukacji.

$\rightarrow$ SŁOWA KLUCZE: ŚRODOWISKO UCZENIA SIĘ, SAMOREGULACJA W UCZENIU SIĘ, NAUCZANIE ZDALNE, COVID-19, WYCHOWANIE 


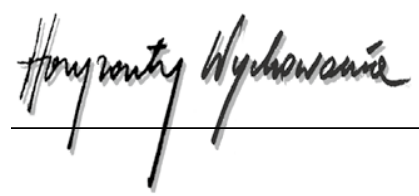

ABSTRACT

The Role of a Learning Environment in the Development of Self-regulated Learning in a Distance Education

RESEARCH OBJECTIVE: The aim of the article is to show the role of the student's environment and social resources in the development of self-regulated learning while attending distance classes in the time of COVID-19

THE RESEARCH PROBLEM AND METHODS: The research problem focuses on finding answers to the following questions: What is self-regulated learning? What is the role of the learner's environment and social resources in fostering self-regulated learning in a virtual classroom during the COVID-19 pandemic? What is the role of adults in organizing the learning environment for their children? Is tutorial conducive to strategic behaviour? The research method is a critical literature review.

THE PROCESS OF ARGUMENTATION: Based on the literature review, a self-regulated learner profile was developed. The results of research concerning the influence of remarkable people from the home environment on the development of child's learning skills were presented and analyzed. It was explained how parents' and private teachers' activities, can support an online schooling in creating conditions conducive to learning during the period of distance education.

RESEARCH RESULTS: The work presents a broad perspective on supporting the student in learning how to learn. The analyses indicate that the ability to learn can be developed in various ways by remarkable persons from the student's environment. It has also been shown that private tutors' work with the student, does not only compensates the learning gap, but it also prepares the student for self-education. Certain adults' beliefs, and coming from them messages directed towards children can have an impact on the further learning activities of the learner.

CONCLUSIONS, INNOVATIONS, AND RECOMMENDATIONS: A remarkable adult plays a very important role in shaping self-regulated learning. The involvement and the use of the student's social resources is a key element of distance education. Therefore, raising awareness among parents about self-regulated learning should be a priority task for all educators.

$\rightarrow$ KEYWORDS: LEARNING ENVIRONMENT, SELF REGULATED LEARNING, DISTANCE LEARNING, COVID-19, UPBRINGING

\section{Wstęp}

Badania dotyczące zdalnego nauczania prowadzone w czasie pandemii COVID-19 ujawniły pogorszenie samopoczucia uczniów. Około 10\% badanej młodzieży odczuwało wyraźnie symptomy nastroju depresyjnego: smutek, samotność, przygnębienie czy płaczliwość (Ptaszek i in., 2020, s. 89). Wielu z nich borykało się z problemami psychosomatycznymi. Trudności z zasypianiem doświadczyło $60 \%$ badanej młodzieży. Uczniowie zauważali też, że częstą przyczyną złego samopoczucia było przeciążenie nauką. 
Uskarżali się, że nauczyciele zadają im zbyt dużo materiału do nauczenia (Ptaszek i in., 2020, s. 29). Zaskakujące jest to, że nawet ci, którzy deklarowali, że ich nauka przebiega pomyślnie, jednocześnie twierdzili, że mają problemy z zarządzaniem własnym uczeniem (Niemi i Kousa, 2020). Przyczyną takiego stanu rzeczy było stosowanie przez nauczycieli metod opartych na nauczaniu podającym, przekazywaniu i weryfikacji wiedzy, a nie zmierzających do rozwoju kompetencji, w tym kompetencji metapoznawczych. Do najczęściej stosowanych metod należało: wyświetlanie filmów i prezentacji, publikowanie materiałów na stronie internetowej lub blogu (Ptaszek i in., 2020, s. 66).

Wyniki badań, doświadczenia i obserwacje pokazały, że skuteczna realizacja zdalnej nauki wymagała udzielenia dzieciom wsparcia ze strony rodziców w zakresie rozwijania umiejętności uczenia się (Pyżalski, 2020). Celem artykułu jest ukazanie działań rodzica lub innej osoby znaczącej zmierzających do rozwoju samoregulacji w uczeniu się w czasie nauczania zdalnego.

\section{Samoregulacja w uczeniu się - wyjaśnienie pojęcia}

Samoregulacja stała się przedmiotem badań prowadzonych w latach 90 . ubiegłego wieku. Popularność tej kategorii wzrosła wraz z narodzinami psychologii poznawczej, która zakłada, że uczący się jest jednostką proaktywną. Przyjęcie takiego założenia stało się podstawą modeli samoregulacji w uczeniu się. Do najstarszych teoretycznych modeli samoregulacji należy model dobrego użytkownika strategii (Good Strategy User). Jego autorzy, Michael Pressley, John Borkowski oraz Wolfgang Schneider (1987), założyli, że sukces w nauce zależy od pewnych cech i zachowań uczącego się, które opisane są za pomocą pięciu komponentów. Uczący się: (1) stosuje strategie, aby zrealizować założony cel; (2) wie, jak, kiedy i gdzie zastosować strategie uczenia się; (3) zdaje sobie sprawę, że uzyskanie wysokich osiągnięć wiąże się z wysiłkiem w stosowaniu strategii oraz z unikaniem negatywnych emocji i niszczącej konkurencji; (4) wykazuje się wiedzą ogólną (non-strategic knowledge) oraz przedmiotową (domain-specific knowledge); (5) posiada umiejętności automatyzacji oraz koordynacji powyższych elementów (Pressley i in., 1987, s. 89-90).

Do wiodących i współczesnych twórców modeli należy Monique Boekaerts, która uwzględniła wyniki badań z zakresu metapoznania i metamotywacji. Jej zdaniem uczeń o wysokiej samoregulacji w uczeniu się powinien posiadać sześć rodzajów wiedzy opartych na trzech poziomach: przedmiotowych, strategicznych oraz poziomie celów. Trzy pierwsze rodzaje wiedzy dotyczą regulacji poznawczej, trzy kolejne - samoregulacji motywacyjnej. Na poziomie wiedzy przedmiotowej mieści się wiedza deklaratywna i proceduralna. Na kolejnym poziomie, strategicznym, znajdują się strategie przetwarzania informacji, selektywnej uwagi oraz odkodowywania. Ostatni poziom zawiera strategie regulacji, do których należą: formułowanie celów, planu uczenia się oraz monitorowania i ewaluacji. Charakteryzując motywację samoregulacyjną, Boekaerts umieszcza wiedzę metapoznawczą oraz sądy motywacyjne na poziomie wiedzy przedmiotowej. 


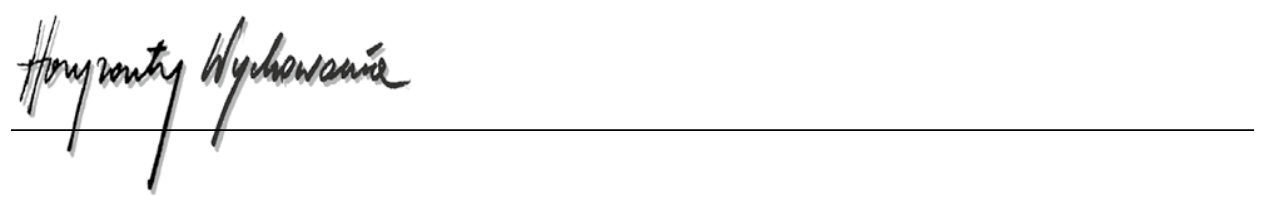

Na poziomie strategicznym komponentu motywacyjnego autorka wylicza atrybucje prospektywne oraz retrospektywne, strategie obronne oraz wykorzystanie zasobów społecznych. Poziom celów uwzględnia motywacyjne strategie regulacji, sformułowanie zamiaru uczenia się, wiązanie zamiarów z planami uczenia się, utrzymywanie kierunku działania (1991, 1992, 1993, 1994, za: Ledzińska i Czerniawska, 2011, s. 110-111; Czerniawska, 1999, s. 9).

W inny sposób samoregulację w uczeniu się opisuje Barry Zimmerman. Autor ten twierdzi, że samoregulacja jest złożonym procesem zawierającym komponenty metapoznawcze, motywacyjne i behawioralne. Sytuując swój model w teorii poznania społecznego, przekonuje, że rozwój umiejętności samoregulacyjnych związany jest również z poczuciem własnej skuteczności (self-efficacy) lub z przekonaniami na temat własnych umiejętności uczenia się (Schunk i Zimmerman, 1997).

Ucznia o wysokiej samoregulacji zgodnie z założeniami powyższych modeli cechują następujące zachowania: stawianie celów, wykorzystywanie wiedzy uprzedniej, dobieranie strategii uczenia się, opracowywanie planu uczenia się (Dembo, 1997, s. 95; Ledzińska i Czerniawska, 2011, s. 108). Uczeń samoregulujący nie traktuje sytuacji uczenia się jako sprawdzianu zdolności czy wiedzy, ale widzi w niej okazję, aby się czegoś nauczyć. Ponadto potrafi monitorować swoje uczenie się, co oznacza, że ma zdolność świadomej autoewaluacji i autorefleksji. W przypadku trudności jest aktywny w poszukiwaniu źródeł wiedzy, szuka też pomocy u kompetentnych osób. Ma poczucie sprawstwa i własnej skuteczności. Oznacza to, że trafnie potrafi ocenić, czy posiada umiejętności potrzebne do realizacji określonego celu (Filipiak, 2012, s. 74).

Szerokie spojrzenie na samoregulację oferuje metoda Self-Reg autorstwa Stuarta Shankera i Teresy Barker, która jawi się jako pomoc w radzeniu sobie ze stresem związanym z nowymi warunkami funkcjonowania w pandemii. Zdaniem autorów samoregulacja obejmuje pięć wymiarów, które oddziałują na siebie i tworzą spójny system. Należą do nich: obszar biologiczny, emocjonalny, poznawczy, społeczny i prospołeczny. Każdy z nich może być źródłem stresorów. Zadaniem dorosłego jest wspieranie dzieci w nauce rozpoznawania i rozumienia aktualnego stanu fizycznego, emocjonalnego (swojego i innych ludzi), sygnałów społecznych, trudności w uczeniu się i utrzymywaniu uwagi (2016, s. 81-86).

\section{Tworzenie warunków do rozwijania samoregulacji w uczeniu się w ramach środowiska domowego}

Nowa rzeczywistość pandemiczna wygenerowała negatywne emocje: niepewność, niepokój, a nawet strach. Poczucie zagrożenia jest silnym stresorem, czynnikiem uruchamiającym aktywność odpowiednich części podwzgórza, wyspy, ciał migdałowatych i układu limbicznego. W rezultacie następuje spadek aktywności poznawczej, motywacji czy zainteresowań (Kaczmarzyk, 2020, s. 24; por. Shanker i Barker, 2016). Stres dotyczył w szczególności osób objętych kwarantanną lub izolacją. Przyczyn takiego stanu rzeczy 
było wiele: przepracowanie (łączenie obowiązków domowych i zawodowych), brak aktywności fizycznej i interakcji społecznych, a także lęk przed skutkami infekcji. Taka sytuacja osłabiała u rodziców naturalną zdolność do odgrywania przez nich roli wspierających opiekunów dla swoich dzieci (Spinelli i in., 2020). Z badań przeprowadzonych przez Pozzoli i współpracowników (2020) wynika, że dzieci, które w domu miały pozytywną atmosferę wychowawczą, doświadczały mniej problemów, ucząc się w trybie zdalnym.

Sam Redding (2002) wyjaśnia, w jaki sposób działania pedagogiczne rodziców lub innych osób znaczących mogą wspomóc szkołę w tworzeniu warunków do uczenia się. Działania te autor podzielił na trzy kategorie: relacja rodzic - dziecko, procedury życia domowego oraz oczekiwania rodziców. Istotną strategią w budowaniu relacji na linii rodzic - dziecko jest stosowanie metod autorytatywnych i unikanie autorytarnych, które wymuszają uległość i bezdyskusyjność. Autorytatywni rodzice uzasadniają swoje postępowanie i stawiane wymagania, tak aby dziecko zrozumiało, że mają na względzie jego dobro. McCaslin i Good przytaczają następujące autorytatywne oddziaływania wychowawcze: (1) komunikowanie się oparte na ciepłych kontaktach; (2) nauczanie prospołecznych wartości i zasad przy jednoczesnym traktowaniu dziecka jako osoby odpowiedzialnej i prospołecznej; (3) określanie zasad przy udziale dziecka w stopniu na tyle elastycznym, aby można je było modyfikować wraz z kolejnym etapem rozwojowym (1992, za: Brophy, 2012, s. 36-37). Wymienione metody służą zwiększeniu motywacji, wprowadzeniu pozytywnego klimatu i wzmocnieniu rezyliencji oraz przygotowują grunt pod rozwój samoregulacji w uczeniu się. Redding (2002) przypomina o oczywistych, ale często zapominanych codziennych czynnościach, które budują bliski kontakt, a jednocześnie rozwijają umiejętność uczenia się. Należą do nich: wspólne wizyty rodzinne w muzeach, zachęcanie dzieci do poszerzania słownictwa, wspólne odkrywanie nowych znaczeń, rozmowy na temat codziennych wydarzeń mających miejsce podczas nauczania zdalnego, dyskusje na temat książek, gazet. Rozmowy te mogą też dotyczyć rodzajów czynności czy typów uczenia się, które sprzyjają nauce, oraz tego, co zrobić, aby uczenie się stało się bardziej wartościowe (por. Brophy, 2012).

W ramach codziennej domowej rutyny Redding (2002) wyróżnia jasny podział czasu na wykonanie poszczególnych czynności: naukę, jedzenie, spanie, zabawę, czytanie, odpoczynek („nicnierobienie”), ruch na świeżym powietrzu. Rozwiązania organizacyjne w nieustannie tworzącej się szkole zdalnej podlegają ciągłym zmianom, a na ich podstawie modyfikowana będzie lub całkowicie zmieniana rutyna domowa, metody dydaktyczne i wychowawcze podejmowane przez dorosłych. Ważne jest, aby wszyscy uczestnicy nauczania zdalnego dawali sobie przyzwolenie na popełnianie błędów w procesie budowania lepszej szkoły (Witkowski, 2020). Lepszemu zarządzaniu czasem oraz podejmowaniu przez uczniów współodpowiedzialności za przebieg uczenia się sprzyja ich wiedza na temat planu nauki w poszczególnych tygodniach: „Zorientowanie się w planach nauczyciela ułatwi im zrozumienie, czego on od nich oczekuje i jaki sens ma zapisany w scenariuszu przebieg zajęć" (Gołębniak, 2019, s. 944).

Organizowanie przestrzeni do uczenia się to kolejny istotny element zdalnej edukacji. Zdaniem Filipiak „środowisko fizyczne stanowi ramy, w których odbywa się proces 


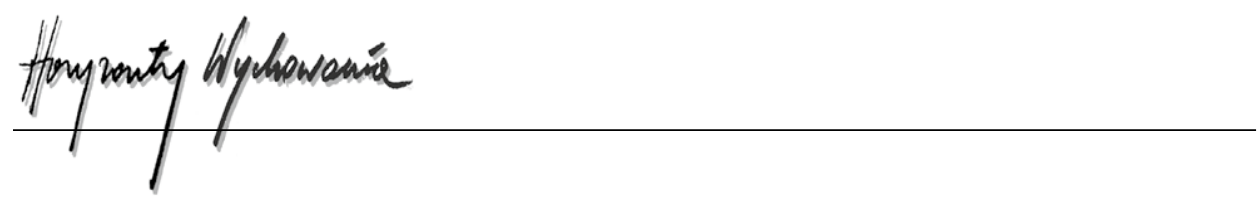

nauczania - uczenia się" (2012, s. 132). Organizując przestrzeń do uczenia się, warto zadbać, aby na zdalną naukę przeznaczyć osobne pomieszczenie. Niekiedy jednak nawet po spełnieniu tego warunku uczniowi trudno odfiltrować dystraktory pojawiające się w domu. Zaleca się wówczas instruowanie dzieci, jak koncentrować się na nauce. Do takich działań należą: utrzymywanie koncentracji na celach, ustanowienie powiązania z nagrodami (zasada Premacka), unikanie kontaktu wzrokowego z czynnikami odwracającymi uwagę, protestowanie („Próbuję się skoncentrować, proszę o ciszę”). Walter ujmuje w sposób lapidarny, jak pomóc uczniowi przygotować warunki do uczenia się: „wyobraź sobie, że zapraszasz szkołę do swojego pokoju - przygotuj miejsce pracy, zadbaj o przydatne materiały oraz o swój wygląd, spróbuj znaleźć takie miejsce, w którym nikt i nic nie będzie ci przeszkadzało" (2020, s. 58).

\section{Korepetytor a zachowanie strategiczne uczniów}

Badania CBOS z roku 2020 dotyczące roku szkolnego rozpoczynającego się w czasie pandemii COVID 19 pokazują, że tylko 46\% rodziców podjęło decyzję o nieposyłaniu dzieci na płatne zajęcia dodatkowe. Analiza danych potwierdza, że najpopularniejszym rodzajem płatnych zajęć edukacyjnych jest nauka języków obcych, którą finansowało lub zamierzało sfinansować $38 \%$ rodzin. Z kolei $20 \%$ rodziców zdecydowało się na opłacenie innych korepetycji oraz kursów przygotowawczych ${ }^{1}$ (CBOS, 2020, s. 7). Zjawisko korepetycji stało się przedmiotem licznych badań już w latach 90. ubiegłego wieku, między innymi za sprawą publikacji Marka Braya The shadow education system: private tutoring and its implications for planners (1999). W kolejnych pracach autor wskazuje na konieczność monitorowania i analizowania tego zjawiska, skupiając się na wadach i zaletach tej formy edukacyjnej. Ze względu na tematykę niniejszej publikacji poniżej zaprezentowano korzyści, jakie czerpie uczeń decydujący się na tę formę nauki. Według Braya (2012) korepetycje przeciwdziałają bezradności i zwalczają wyuczoną bezradność. W niektórych krajach działają centra edukacyjne (np. Kumon), które indywidualizując naukę, rozwijają potencjał dziecka i jego zaangażowanie w naukę. Uczestnictwo w korepetycjach pomaga uczniowi w zrozumieniu materiału lekcyjnego czy przygotowaniu się do egzaminów zewnętrznych (Bray, 2012, s. 65-66). Listę korzyści uzupełniają wyniki badań Magdaleny Kolber (2012, 2021), zgodnie z którymi korzystanie z korepetycji w zakresie języka angielskiego koreluje z wyższym zachowaniem strategicznym uczniów². Potwierdzono, że licealistów, którzy pobierają dodatkowe lekcje, cechuje wyższy poziom stosowania strategii pamięciowych, poznawczych, metakognitywnych, emocjonalnych, społecznych. Do przykładowych zachowań strategicznych w ramach wyżej wymienionych grup strategii należą: tworzenie powiązań w umyśle, stosowanie obrazów i dźwięków,

\footnotetext{
${ }^{1} \mathrm{Na}$ opłacanie zajęć artystycznych zdecydowało się 16\% polskich rodzin, a zajęć sportowych $-27 \%$.

${ }^{2}$ W badaniu zastosowano narzędzie oraz taksonomię R. Oxford (1990).
} 
ćwiczenia, otrzymywanie i wysyłanie wiadomości, analizowanie i rozumowanie, strategie pomagające ześrodkować proces uczenia się na celu, planowanie uczenia się, strategie dotyczące ewaluacji uczenia się, strategie związane z obniżeniem poziomu niepokoju, samozachęta, mierzenie temperatury emocjonalnej; współpraca i współodczuwanie z innymi. W związku z tym, że uczniowie uczęszczający na zajęcia dodatkowe (w tym korepetycje) wykazują wyższe zachowania strategiczne, można wysnuć wniosek, że pracując indywidualnie, korepetytorzy często wchodzą w rolę tutorów, którzy rozwijają samoregulację w uczeniu się, motywując i zachęcając do stosowania strategii przetwarzania informacji i nabywania umiejętności. Edukacja zdalna nakłada na korepetytora nowe obowiązki. Jego rola polega nie tylko na budowaniu rusztowania dla budowania myślenia o procesach poznawczych czy przekazywaniu uczniom skutecznych sposobów uczenia się, ale również na rozwijaniu w uczniach umiejętności świadomego dostosowania procesu uczenia się do zmieniających się okoliczności i zadań (por. Carter, 2020).

\section{Przekonania rodziców a rozwijanie samoregulacji w uczeniu się}

Określone oczekiwania dorosłego odnośnie do osiągnięć dzieci są powiązane z ich sukcesami w nauce. Na przykład eksperyment Harolda Stevensona i współpracowników3 ${ }^{3}$ (1990) dowiódł, że dzieci mające wysokie osiągnięcia szkolne pochodzą z rodzin, w których rodzice mają realistyczne oczekiwania wobec osiągnięć szkolnych, potrafią trafnie ocenić możliwości akademickie, poznawcze oraz cechy osobowościowe swojego dziecka. Co więcej, autorzy ci podkreślają znaczenie ciężkiej pracy, a nie wrodzonych zdolności.

Podobnym wątkiem zajęła się w swoich badaniach Carol Dweck. Badaczka odkryła, że istnieją dwie kategorie ludzi: osoby nastawione na trwanie (fixed mindset) i osoby nastawione na rozwój (growth mindset) (Dweck, 2013; por. Kolber, 2014a, 2014b). Przyjęcie określonego przekonania przez uczącego się ma wpływ na rodzaj podejmowanej przez niego aktywności samoregulacyjnej (lub na jej brak). Pierwsza grupa ludzi żywi przekonanie, że ich cechy, na przykład inteligencja, są niezmienne („Czy jesteś wystarczająco inteligentny(-a), aby rozwiązać to zadanie?”). Osoby te wierzą, że umiejętności, wysoka inteligencja są wrodzone: ,jeśli masz talent, to go masz, a jeżeli go nie masz, to go nie masz" (Dweck, 2013, s. 31). Gdy myślą o zadaniach szkolnych, przyświeca im cel wykonaniowy (performance goal), który wynika z chęci uzyskania przez nich stopni wyższych niż ich rówieśnicy (Dweck, 1985, za: Dembo, 1997, s. 142). Z taką postawą związane są pewne sposoby uczenia się oraz zachowania uczącego się. Do preferowanych strategii uczenia się należą strategie płytkie: zapamiętywanie i powtarzanie oraz unikanie myślenia krytycznego i rozwiązywania problemów (Maehr i Anderman, 1993,

${ }^{3}$ Badanie dotyczyło osiągnięć w czytaniu i matematyce, porównywano osiągnięcia dzieci chińskich i japońskich oraz amerykańskich. 


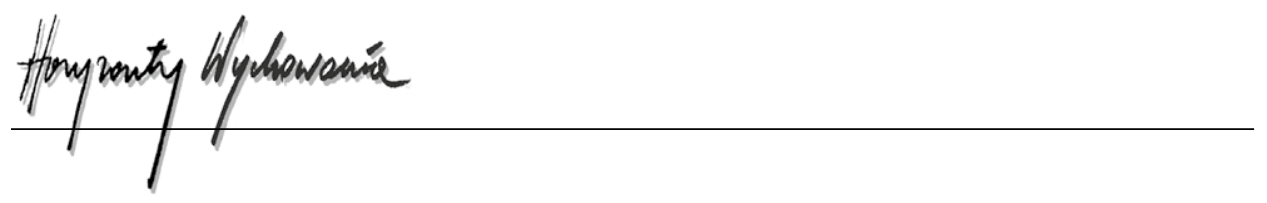

za: Dembo, 1997, s. 142). W przypadku porażki osoby takie wybierają bierność lub zaprzestanie działania.

Druga grupa wyszczególniona przez Dweck, nastawiona na rozwój, wierzy, że inteligencja, osobowość podlegają rozwojowi („Czy jeszcze tego nie rozwiązałeś(-aś)?”). Koncentracja na rozwoju sprawia, że osoby takie dostrzegają korzyści z własnej aktywności poznawczej. Często podejmują wyzwania, a w przypadku porażki nie poddają się (Dweck, 2013; por. Turska, 2012). Uważają, że przyczyną ich porażki był niedostateczny wysiłek lub niewłaściwy dobór strategii. Szukają zatem nowych, bardziej skutecznych sposobów, które pomogą im osiągnąć założone cele.

Teoria Dweck została potwierdzona przez Lisę Blackwell i jej współpracowników. Grupa badaczy przeprowadziła eksperyment wśród amerykańskich uczniów klasy 7, którzy uzyskali niskie wyniki z matematyki (Blackwell i in., 2007, za: Dweck, 2010, s. 27). Uczniowie zostali podzieleni na dwie grupy. Grupa kontrolna brała udział w zajęciach uczenia, jak się uczyć, natomiast grupa eksperymentalna oprócz treningu uczenia się, jak się uczyć, otrzymała możliwość udziału w programie informacyjnym, podczas którego uczniowie dowiedzieli się, że: (1) mózg działa jak mięsień, trenowany staje się silniejszy, (2) mózg tworzy połączenia między neuronami podczas zaangażowania w nowe zadania, (3) nie talent czy inteligencja powodują, że uczniowie odniosą sukces, ale ich ciężka praca i wysiłek. Wyniki eksperymentu pokazały, że uczniowie z grupy eksperymentalnej byli bardziej zmotywowani, aby wykorzystać sposoby uczenia się, i tym samym znacznie poprawili swoje wyniki z matematyki w stosunku do grupy kontrolnej.

Teoria Dweck wskazuje na pewne drogi postępowania rodziców prowadzące do rozwijania u dzieci nastawienia na trwałość i umiejętności radzenia sobie z porażką, a także do formułowania właściwych komunikatów wobec dziecka. Przede wszystkim należy akcentować kwestię plastyczności mózgu, a także rolę umiejętności uczenia się oraz czerpania korzyści z doświadczeń.

Paweł Fortuna (2013) przekonuje, że niepowodzenie może doprowadzić do pozytywnych zmian. Należą do nich: nauka umiejętności wyciągania wniosków na przyszłość, kształtowanie cnót kardynalnych oraz sił charakteru, wzmacnianie pokory, przeciwdziałanie lękowi przed porażką, odkrycie, że przykre doświadczenia dostarczają nam wartościowych informacji na nasz temat. Rodzic może kształtować u swoich dzieci otwartość na porażkę od najmłodszych lat. Wskazówkę ujmuje Fortuna w następujących słowach: „Daj im trochę swobody. Twój potomek nie jest narzędziem realizacji Twoich aspiracji. Pokaż mu, ile przyjemności można czerpać z samego żeglowania, a nie tylko z zawijania do docelowego portu" (2013, s. 251). Istotny jest również sposób wyjaśniania niepowodzeń oraz radzenia sobie z nimi. Badania nad korektywą atrybucji pozwoliły sformułować kilka istotnych wskazówek w tym zakresie. Należą do nich: przypisywanie porażki niedostatecznemu wysiłkowi („za mało pracowałeś(-aś)”), tłumaczenie porażki użyciem niewłaściwych strategii („następnym razem spróbuj innego sposobu”), prezentowanie biografii osób, które osiągnęły sukces mimo licznych niepowodzeń (por. Dembo, 1997). 


\section{Podsumowanie}

Uczenie się w domu samodzielnie czy przy wsparciu rodziców jest znacznie trudniejsze i bardziej wymagające w porównaniu do uczenia się stacjonarnego w szkole pod kierunkiem nauczyciela. Z tego względu współpraca rodziców z nauczycielami w dobie pandemii stała się jeszcze ważniejsza niż zazwyczaj. Zaangażowanie oraz wykorzystanie zasobów społecznych ucznia (członków rodziny, innych znaczących dorosłych: przyjaciół, znajomych, sąsiadów, korepetytorów) stanowi kluczowy element zdalnej edukacji. Pogląd na ten temat najlepiej obrazują słowa Anny Izabeli Brzezińskiej:

Im lepiej nauczyciel i uczniowie wykorzystają swoje osobiste i społeczne zasoby, tym skuteczniejsza jest między nimi wymiana w procesie edukacji na każdej lekcji i tym, w konsekwencji, lepsze efekty dydaktyczne i wychowawcze (2008, s. 41).

Szczególnie w przypadku dzieci młodszych nie bez znaczenia pozostaje płynna komunikacja nauczyciela z uczniem i jego rodzicem, a także kształcenie rodziców oraz innych bliskich dziecku osób w zakresie szerokiego spojrzenia na rozwijanie samoregulacji w uczeniu się.

\section{BIBLIOGRAFIA}

Bray, M. (1999). The shadow education system: private tutoring and its implications for planners. https://unesdoc.unesco.org/ark:/48223/pf0000180205/PDF/180205eng.pdf.multi

Bray, M. (2012). Korepetycje. Cień rzucany przez szkoły (K. Chodzińska, tłum.). Wydawnictwo Wolters Kluwer Polska.

Brophy, J. (2012). Motywowanie uczniów do nauki (K. Kruszewski, tłum.). Wydawnictwo Naukowe PWN

Brzezińska, A.I. (2008). Nauczyciel jako organizator społecznego środowiska uczenia się. W: E. Filipiak (red.), Rozwijanie zdolności uczenia się. Wybrane konteksty i problemy (s. 35-49). Wydawnictwo UKW.

Carter Jr, R.A., Rice, M., Yang, S. i Jackson, H.A. (2020). Self-regulated learning in online learning environments: strategies for remote learning. Information and Learning Sciences, 121(5/6), 321-329. https://www.emerald.com/insight/content/doi/10.1108/lLS-04-2020-0114/full/html

CBOS. (2020). Wydatki rodziców na edukację dzieci w roku szkolnym 2020/2021. https://www. cbos.pl/SPISKOM.POL/2020/K 136 20.PDF

Czerniawska, E. (1999). Samoregulacja w uczeniu się. Modele teoretyczne. Forum Psychologiczne, 4(1), 3-17.

Dembo, M.H. (1997). Stosowana psychologia wychowawcza (E. Czerniawska, A. Matczak i Z. Toeplitz, tłum.). Wydawnictwo Naukowe PWN.

Dweck, C. (2010, January). Mind-sets and equitable education. https://www.greatschoolspartnership.org/wp-content/uploads/2016/11/Mindsets-and-Equitable-Education.pdf

Dweck, C. (2013). Nowa psychologia sukcesu (A. Czajkowska, tłum.). Muza SA.

Filipiak, E. (2012). Rozwijanie zdolności uczenia się: z Wygotskim i Brunerem w tle. Gdańskie Wydawnictwo Psychologiczne. 


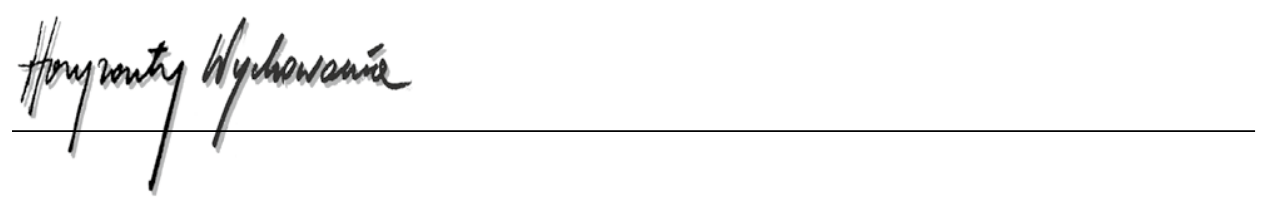

Fortuna, P. (2013). Pozytywna psychologia porażki. Jak z cytryn zrobić lemoniadę. Gdańskie Wydawnictwo Psychologiczne.

Gołębniak, D.B. (2019). Proces kształcenia. W: Z. Kwieciński i B. Śliwerski (red.), Pedagogika. Podręcznik akademicki (s. 857-960). Wydawnictwo Naukowe PWN.

Kaczmarzyk, M. (2020). Neurobiologiczny kontekst edukacji zdalnej. W: J. Pyżalski (red.), Edukacja w czasach pandemii wirusa COVID-19. Z dystansem o tym, co robimy obecnie jako nauczyciele (s. 20-24). EduAkcja.

Kolber, M. (2012). Strategie uczenia się języka obcego a wyuczona bezradność (na przykładzie szkół ponadgimnazjalnych) (niepublikowana praca doktorska). Uniwersytet Kazimierza Wielkiego.

Kolber, M. (2014a). Rola edukacji aktywnej w przezwyciężaniu wyuczonej bezradności na lekcji języka obcego. Lingwistyka Stosowana, 10, 51-60.

Kolber, M. (2014b). Zastosowanie psychologii pozytywnej w edukacji. Przegląd Pedagogiczny, 2, 156-165.

Kolber, M. (2021) Private supplementary tutoring as an example of controversial practice in the field of education. New contexts and analyses. Przegląd Pedagogiczny (w recenzji).

Ledzińska, M. i Czerniawska, E. (2011). Psychologia nauczania. Ujęcie poznawcze. Wydawnictwo Naukowe PWN.

Niemi, H.M. i Kousa, P. (2020). A case study of students' and teachers' perceptions in a Finnish high school during the COVID pandemic. International Journal of Technology in Education and Science, 4(4), 352-369.

Oxford, R.L. (1990). Language learning strategies: What every teacher should know. Heinle.

Pozzoli, T., Gini, G. i Scrimin, S. (2021). Distance learning during the COVID-19 lockdown in Italy: The role of family, school, and individual factors. School Psychology. http://dx.doi.org/10.1037/ spq0000437

Pressley, M., Borkowski, J.G. i Schneider, W. (1987). Cognitive strategies: good strategy users coordinate metacognition and knowledge. Annals of Child Development, 4, 89-129.

Ptaszek, G., Stunża, G.D., Pyżalski, J., Dębski, M. i Bigaj, M. (2020). Edukacja zdalna: co stało się z uczniami, ich rodzicami i nauczycielami? Gdańskie Wydawnictwo Psychologiczne.

Pyżalski, J. (red.) (2020). Edukacja w czasach pandemii wirusa COVID-19. Z dystansem o tym, co robimy obecnie jako nauczyciele. EduAkcja.

Redding, S. (2002). Parents and learning. International Academy of Education. https://www.iaoed. org/downloads/prac02e.pdf

Shanker, S. i Barker T. (2016). Self-Reg. Jak pomóc dziecku (i sobie) nie dać się stresowi i żyć pełnią możliwości (N. Fedan, tłum.). Mamania.

Schunk, D.H. i Zimmerman, B.J. (1997). Social origins of self-regulatory competence. Educational Psychologist, 32, 195-208.

Spinelli, M., Lionetti, F., Pastore, M. i Fasolo, M. (2020, 3 lipca). Parents'stress and children's psychological problems in families facing the COVID-19 outbreak in Italy. https://www.frontiersin. org/articles/10.3389/fpsyg.2020.01713/full

Stevenson, H., Lee, S., Chen, C., Stigler, J., Hsu, C., Kitamura, S. i Hatano, G. (1990). Contexts of achievement: A study of American, Chinese, and Japanese children. Monographs of the Society for Research in Child Development, 55(1-2), 1-116.

Turska, D. (2012). „Teorie” inteligencji Carol Dweck i ich edukacyjne implikacje. Psychologia Wychowawcza, 12, 44-54.

Walter N. (2020). Mamy (za) duży wybór - jak nie zgubić się wśród narzędzi cyfrowych? W: J. Pyżalski (red.), Edukacja w czasach pandemii wirusa COVID-19. Z dystansem o tym, co robimy obecnie jako nauczyciele (s. 51-58). EduAkcja. 
Rola środowiska ucznia w rozwijaniu samoregulacji w uczeniu się

Witkowski, J. (2020). Organizacja zdalnego nauczania. W: J. Pyżalski (red.), Edukacja w czasach pandemii wirusa COVID-19. Z dystansem o tym, co robimy obecnie jako nauczyciele (s. 8696). EduAkcja.

\section{Copyright and License}

This article is published under the terms of the Creative Commons Attribution - NoDerivs (CC BY- ND 4.0) License

http://creativecommons.org/licenses/by-nd/4.0/ 